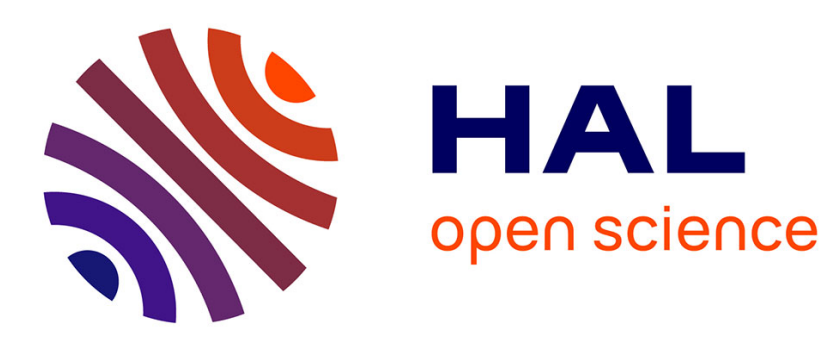

\title{
Designing ecolabels in order to mitigate market failures: an application to agrofood products
}

\author{
Douadia Bougherara, Gilles Grolleau
}

\section{To cite this version:}

Douadia Bougherara, Gilles Grolleau. Designing ecolabels in order to mitigate market failures: an application to agrofood products. Journal of Interdisciplinary Economics, 2005, 26 (4), pp.411-430. hal-01939943

\section{HAL Id: hal-01939943 \\ https://hal.science/hal-01939943}

Submitted on 29 Nov 2018

HAL is a multi-disciplinary open access archive for the deposit and dissemination of scientific research documents, whether they are published or not. The documents may come from teaching and research institutions in France or abroad, or from public or private research centers.
L'archive ouverte pluridisciplinaire HAL, est destinée au dépôt et à la diffusion de documents scientifiques de niveau recherche, publiés ou non, émanant des établissements d'enseignement et de recherche français ou étrangers, des laboratoires publics ou privés. 


\title{
Designing Ecolabels In Order To Mitigate Market Failures ${ }^{1}$ An Application to Agrofood Products
}

\section{Douadia Bougherara*}

Agricultural Economics and Sociology Department, University of Burgundy, France

\section{Gilles Grolleau**}

Agricultural Economics and Sociology Department, University of Burgundy, France

\begin{abstract}
For the market for ecofriendly characteristics of agrofood products to function effectively, means of mitigating asymmetric information, informational overload and public goods properties are necessary. Ecolabel success requires a design and an implementation capable of mitigating simultaneously these three sources of market failures. Our contribution differs from many to date by (1) introducing and analyzing the informational overload as a source of market failure and (2) considering the ecolabel, not only as a tool to reestablish information symmetry between the producer and consumer but also as a way to overcome informational overload and public goods problems. We analyze how these sources of market failures may be mitigated by providing information perceived as trustworthy, tying credence and public attributes to verifiable and private attributes and designing the ecolabel as a cognitive support for consumers. We provide an exploratory qualitative study of several French ecolabels to stress how they more or less succeed in attenuating the identified sources of market failures. Several implications for policymakers and managers are stressed. We conclude by suggesting several issues requiring further investigations.
\end{abstract}

Key words: Ecolabeling; Market failures; Agrofood products.

JEL Classification Numbers: D11, D21, L15

*UMR INRA - ENESAD, Agricultural Economics and Sociology Department, 26 Bd Dr Petitjean BP 8799921079 DIJON CEDEX France

Tel: + 33380772818 - Fax: + 33380772571 - d.bougherara@enesad.inra. fr

Corresponding author:

**UMR INRA - ENESAD, Agricultural Economics and Sociology Department, 


\section{INTRODUCTION}

Many consumers express a willingness to pay for agrofood products that they perceive as less harmful for the environment compared to similar products (Table 1) and producers are willing to market ecofriendly products to capture the consumers' willingness to pay.

The "invisible hand" of free markets fails to provide environmental characteristics ${ }^{2}$ embedded in agrofood products at a Paretian optimum, notably because of information asymmetry. In the academic literature, ecolabeling is mostly presented as a market based tool for addressing the market failure resulting from asymmetric information. Ecolabels can help reduce the asymmetric information between producers and consumers by conveying to consumers information related to environmental impacts of products. Consequently, ecolabels help transform environmental awareness of consumers into consumption changes. However, ecolabels also confront two additional problems capable of disrupting the market mechanism, i.e. the limited abilities of consumers to process increasing flows of information and the public nature of environmental characteristics. The main insight of this paper is to consider whether the ecolabel may simultaneously overcome information asymmetry, information overload and public goods problems.

The paper is organized as follows. Section 2 shows that environmental attributes constitute a source of market failures, which may explain why declarative willingness to pay does not necessarily correspond to effective purchases. Section 3 analyzes how these market failures may be mitigated by several devices such as emphasizing private and verifiable benefits and designing the ecolabel as a trustworthy and cognitive support for consumers. Section 4 provides an exploratory qualitative study of several existing ecolabels on French agrofood products in order to stress how designers take into account and attenuate the previous sources of market failures. Section 5 outlines the relevance of the results for managers and policy makers and concludes.

\section{ENVIRONMENTAL ATTRIBUTES OF AGROFOOD PRODUCTS: A SOURCE OF MARKET FAILURES}

"Eco-labeling can provide the missing market information about production process attributes and be used as a mechanism revealing consumer valuation of environmental attributes of agricultural commodities" (Moon et al., 2002). "The overall purpose of the environmental label derives from the intention to overcome market failures caused by information asymmetries" (Karl and Orwat, 1999). Ecolabeling is frequently considered as a way to overcome the market failure resulting from asymmetric information between the producer 


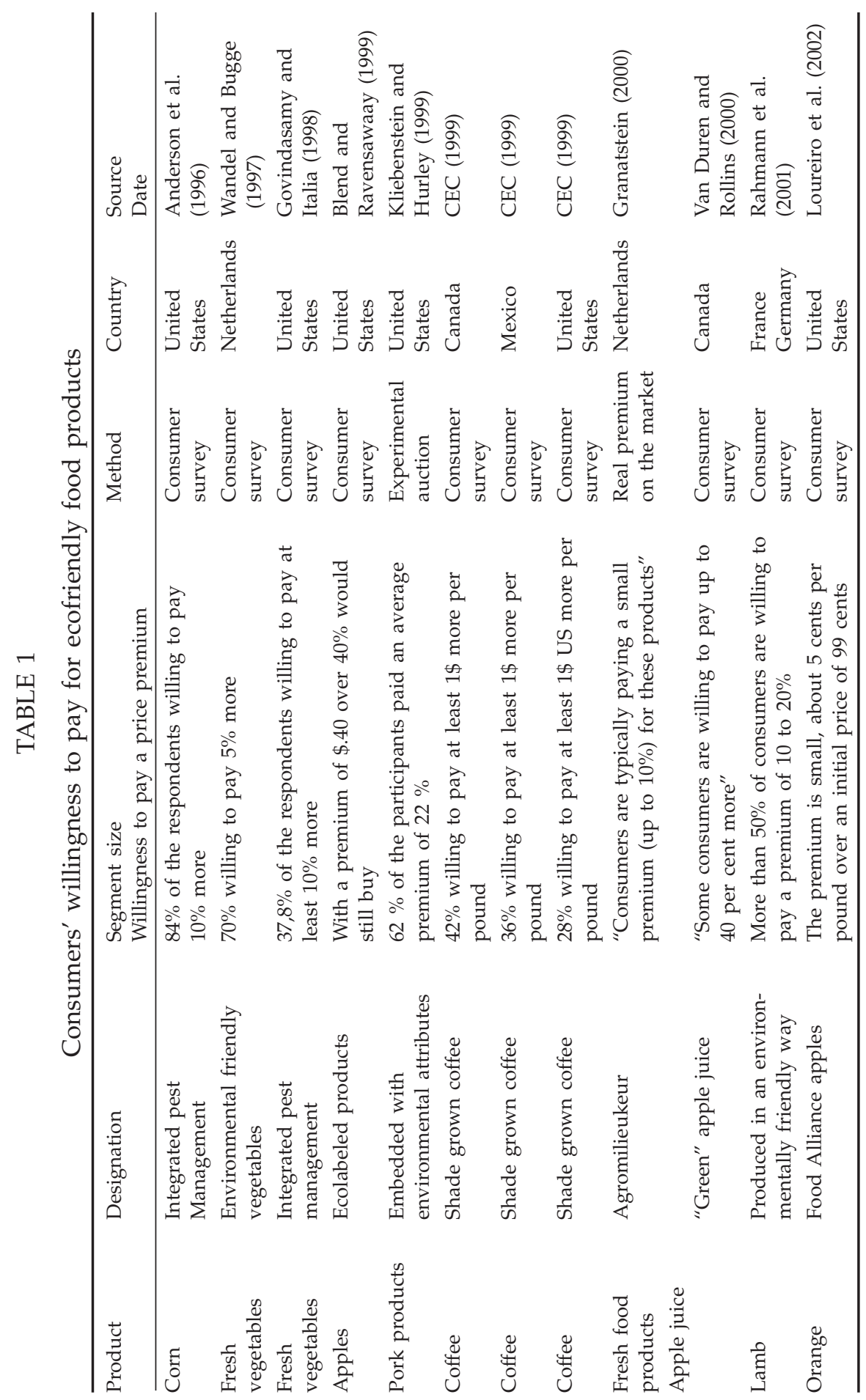


and the consumer. However this view is restrictive, because marketing environmental characteristics involves other market failures which also determine the success of ecolabeling schemes.

\subsection{Asymmetric information between producers and consumers}

Environmental characteristics of agrofood products correspond notably to impacts of farming and processing practices on the environment, which are dissociated from product consumption. For consumers, these environmental attributes are frequently credence goods according to the terms coined by Nelson (1970) and Darby and Karni (1973). According to the considered attribute, consumers will undertake different kinds of expenditures to get "informational input" of their decision making process $^{3}$. In the case of search attributes, consumers inspect the product before purchase. For experience attributes, the most cost-effective way to get the information is to consume the product. If product quality remains constant, consumers can base their future purchases on the information acquired during the first consumption. Credence attributes cannot be accurately and efficiently evaluated even after purchase or consumption, because the consumer lacks technical expertise and/or the cost of acquiring sufficient and accurate information is more costly than its expected value and/or there is no tangible link between the expected attributes and consumption of the product. In most cases, credence attributes are known by producers, but remain hidden to consumers $^{4}$ (Table 2).

This information asymmetry may lead to adverse selection and moral hazard. Adverse selection is ex ante opportunism due to hidden information while moral hazard is an ex post opportunism due to hidden action. Because producing environmental characteristics depends mainly on initial investments done once for all, e.g. acquisition of knowledge, skills, materials, we can consider, at first glance, that the moral hazard framework is inaccurate ${ }^{5}$. If consumers are unable to check environmental characteristics, fraudulent producers can market bad products with a green image and free ride on the ecofriendly market. Consumers anticipate producers' temptation to cheat and then reduce their willingness to pay for environmental friendly products. Honest ecofriendly producers cannot cover their higher production cost and exit the market (Akerlof, 1970).

\subsection{Information overload: a potential source of market failure}

Informational asymmetry differs from informational overload, even if the dividing line is fuzzy. Informational asymmetry corresponds to an 


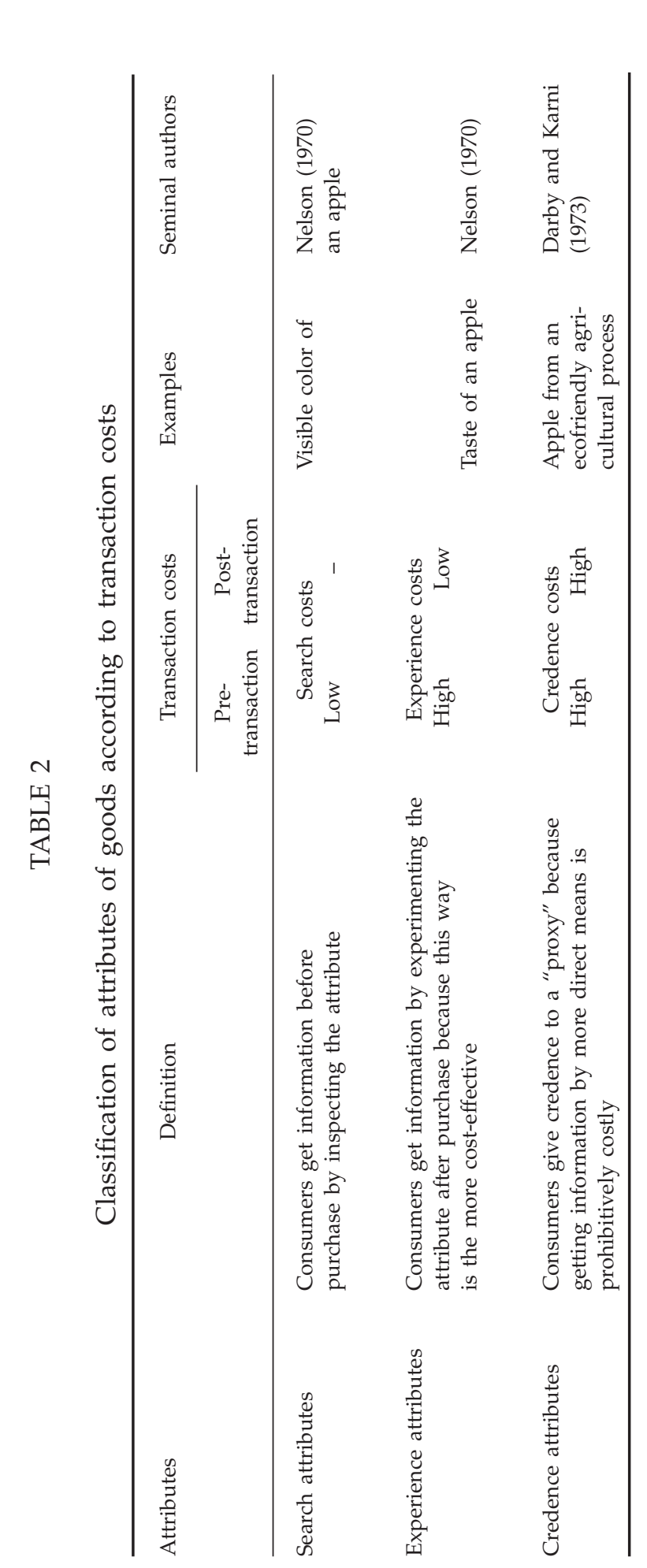


unequal repartition of information between two agents, which allows an opportunistic behavior of the best-informed agent. Informational overload arises because agents have limited cognitive abilities. Even in a world characterized by symmetric information, agents can be overwhelmed by increasing flows of information. If consumers are provided with too much information such that it exceeds their processing limits, overload occurs and may lead to poorer decision making. The consumer notably makes two decisions: (1) how much information to collect and the subsequent likelihood to devote processing abilities and time to useless information and (2) whether to purchase the product with the risk of purchasing a product that does not correspond to his preferences. Under symmetric information, the problem is solely an exogenous (to the consumer) constraint, under the load problem the problem is partially endogenous - the constraint is a consumer-based one and the decision is partially the consumer's (he decides how much information to consume). Note that consumers differ in terms of their cognitive abilities, hence information overload and the optimal level of information is somewhat a consumer specific phenomenon. This obviously complicates labeling design.

More formally, consider a decision maker willing to acquire information. He has to invest more and more resources, e.g. time and money for acquiring additional information. On the one hand, the marginal cost of information assimilation tends to rise exponentially. On the other hand, the marginal benefit of the gathered information, i.e. the extra value to the decision maker of an additional bit of information, rises initially, at a decreasing rate. Up to a certain point, additional information increases the decision maker utility. Beyond an optimal level of information (from the consumer viewpoint), which is frequently lower than the level of symmetric or complete information, the marginal net benefit from processing additional information may be negative because confusion increases. Moreover, information overload may also lead to more (valuable) information being ignored or not used. Note that perceived information overload would be associated with higher satisfaction and lower performance of decision makers than would be perceived information underload (O'Reilly, 1980). The decision procedure described above can be considered as an application of the psychological law of Yerkes-Dodson (1908). The essence of this law is the relationship between performance, e.g. the decision quality and pressure, e.g. the information load (Leibenstein, 1987). If we visualize the decision quality on the ordinate and the information flows on the abscissa, the Yerkes-Dodson law may be represented by a roughly inverted-U curve (Figure 1). As informational load increases, decision quality comes closer to maximization. Beyond some point informational load may be so high that decision makers find it rather difficult to cope. 


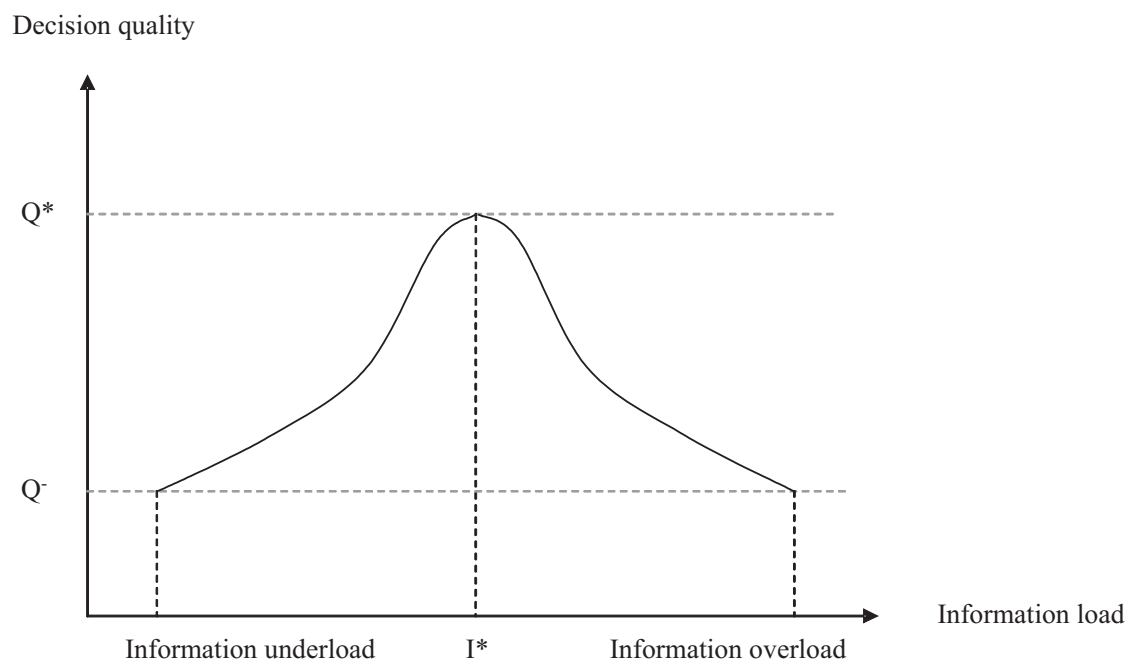

Figure 1. The Yerkes-Dodson law

Consequently, because of limited human processing capacity, agents need to allocate their attention among competitive sources. The consumers' attention becomes the scarcest resource instead of information. Once they devote their attention to given information, they may need to mitigate information asymmetry. Herbert Simon ${ }^{6}$ (1995) recognizes that information symmetry is not enough to ensure market efficiency: "What information consumes is rather obvious: it consumes the attention of its recipients. Hence a wealth of information creates a poverty of attention, and a need to allocate that attention efficiently among the overabundance of information sources that might consume it." Indeed, consumers have less time and limited abilities to process increasing information flows. At first glance, competition for consumers' attention occurs in rich informational context, because the label itself provides too much information or competition between several sources capable of capturing consumers' attention. New information and communication technologies reinforce this situation by providing huge amounts of information. In a well-documented study on different ecolabels, Wynne (1994, p. 95) claims that "simply making information available to consumers in no way assures that they will process it". He shows that environmental report cards ${ }^{7}$ establish symmetrical but useless information because consumers are overloaded by such amounts of information. One must distinguish between "information provision" and "information impact", because there is no one to one relationship between information provided and the impact, if any, of this information on the recipient". Recently, the German Federal Environmental Agency 
have stressed the negative effects of competition between eco-claims and other impulses for attention: "The flood of other ecolabels also poses a problem for the first environmental label [Blue Angel]. A great deal of packaging is meanwhile emblazoned with half-a-dozen badges all of them courting the customer's favor. Attracting attention has become more difficult. (...) The average person is confronted daily with 3000 advertising impulses" (German Federal Environmental Agency, $2002^{8}$ ). An interesting question, but out of scope of this paper, is to identify the specific attributes that tend to be associated with such overload.

\subsection{The public nature of environmental characteristics}

The environmental improvement (or degradation) generated by the environmental characteristics of ecofriendly (conventional) products frequently have a public good nature. The characteristics of nonrivalry and non-excludability imply that the purchase of ecofriendly products does not guarantee to the purchaser an exclusive utility from the environmental improvements generated by his purchase. Generally, environmental impacts are global and consumer verification of the impacts is impossible, such as the state of the ozone layer. Other environmental characteristics correspond to long term horizons, exceeding the consumer's life expectancy. Several environmental characteristics result from the total of polluting emissions generated by a product market. Frequently, it is not feasible to exclude those who do not consume ecofriendly products from the benefits generated by environmentally conscious purchasers, e.g. air quality. Environmental characteristics of agrofood products can affect the welfare of future generations who are unable to express their preferences. Moreover, an individual consumer cannot frequently evaluate the real benefits of his contribution. Consequently, the individual does not bear all the consequences of his decision. Public goods lead to a misallocation of scarce resources because the decision making process does not take into account the whole cost ${ }^{9}$. The private production of these environmental characteristics has to mitigate two distinct but interrelated problems: (1) The free riding problem: Since the environmental improvement is available to everybody, the free riders consume it without purchasing the corresponding ecofriendly product. The presumption of neoclassical economics is that the public good will be under-provided by private and decentralized markets. (2) The assurance problem: The production of a perceptible environmental improvement can require a minimum level of contributions. Consumers are willing to contribute if they are convinced that an adequate threshold of contributions will be reached, i.e. a sufficient number of contributors will also contribute. 
If contributions are insufficient, the environmental improvement will not be produced. Consequently, the individual thinks he will squander his contribution by purchasing an ecofriendly product, corresponding to the "sucker" payoff (Wiener and Doescher, 1991). The assurance problem is especially crucial when environmental quality depends on the environmentally conscious behavior of many consumers.

The three sources of market failures are represented in figure 1, from the most internal problem (inside the individual) to the most external one (the entire context is affected). Individuals may experience an internal conflict between their consumers' preferences and their citizens' preferences. Preference orderings in these two fields are not always compatible ${ }^{10}$. Consumer preferences are about what the consumer wants whereas citizen preferences are about what we should want as a group. Note that Margolis (1982) have proposed a utility function that has more than one domain, $\mathrm{U}=\mathrm{f}\left(\mathrm{U}_{\mathrm{S}^{\prime}}, \mathrm{U}_{\mathrm{G}}\right)$, where $\mathrm{U}_{\mathrm{S}}$ is selfinterested preferences and $U_{G}$ is group-interested preferences. Despite its importance, this question is out of scope of this paper. Moreover, between consumers and sellers, there is a two-sided informational asymmetry. Consumers face a multi-sided situation because of the free riding behavior and the assurance problem among themselves. Lastly, informational overload forces consumers to allocate their attention among different alternatives.

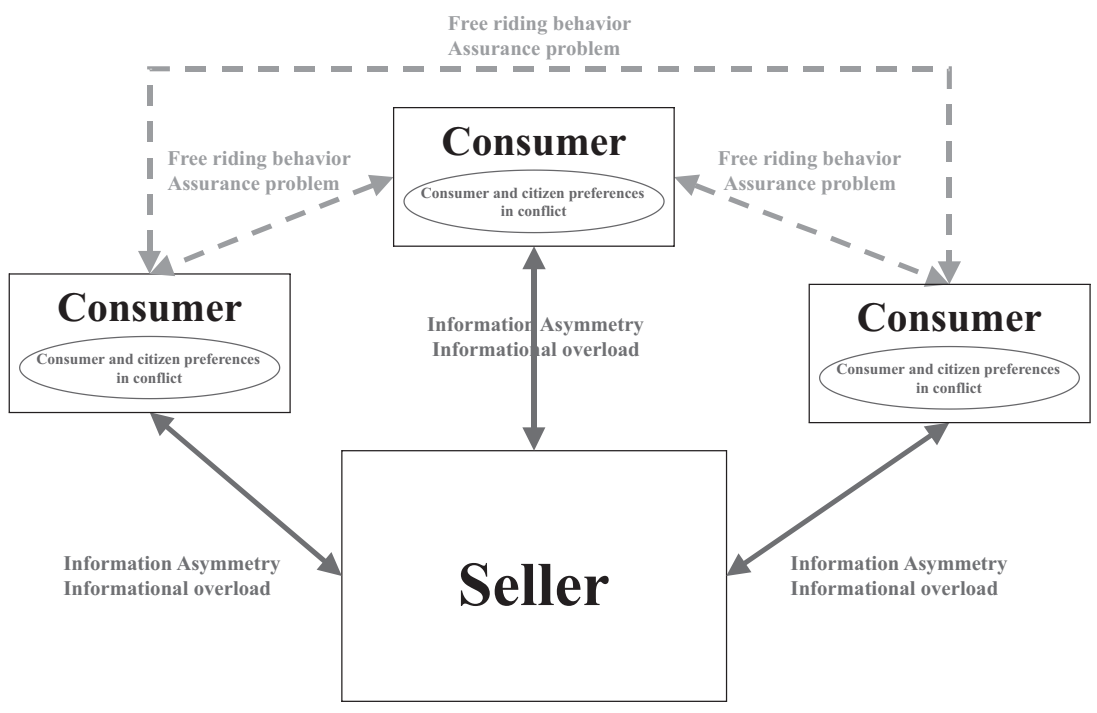

Figure 2. Sources of market failures arising with ecofriendly products 


\section{HOW COULD ECOLABELING CONTRIBUTE TO MITIGATE MARKET FAILURES?}

Ecolabeling schemes constitute an explicit institution including two fundamental components, i.e. a system of rules or principles and a system of enforcement. Although ecolabeling schemes were originally considered as voluntary instruments for addressing informational asymmetry, we have shown that this perspective is not sufficient. To ensure market efficiency, an ecolabel has to mitigate simultaneously several sources of market failures. This section stresses how this aim can be reached for each market failure separately and concludes by considering them together.

\subsection{Tying the ecolabel sign to a trustworthy third party reputation}

To mitigate the adverse selection generated by credence attributes, several authors argue that the participation of third parties with an established reputation for credibility is generally necessary and may constitute a cost effective alternative (Caswell and Modjuszka, 1996; McCluskey, 2000; Sporleder and Goldsmith, 2001). Concretely, the ecolabel sign is frequently tied to the third party certifier - e.g. putting the name or the logo of the certifier - in order to communicate the trustworthy character to consumers. Their role may notably include a participation in (1) the definition stage of what is an ecofriendly food product i.e. the criteria selection allowing to use the ecolabel ${ }^{11}$, (2) the monitoring stage of previously defined criteria to assess product conformity and (3) the signaling stage where producers may use a device allowing to distinguish true ecofriendly products from conventional ones and possibly to rank among different levels of ecofriendliness ${ }^{12}$. Each stage is vulnerable to opportunistic behaviors. Consequently the transaction costs implied to achieve a credible procedure may become excessive and swallow up consumers' willingness to pay.

\subsection{Designing the ecolabel as a cognitive support for consumers}

In an environment overloaded with information, the success of ecolabels depends on its abilities to capture the consumer's attention rather than only providing factual, correct and complete information unprocessable by consumers. Ecolabels design matters. Instead of spending excessive money in direct measurement, consumers search for a cognitive support capable of capturing attention and summarize complex information, e.g. an eco-seal of approval. Teisl and Roe (1998) make the argument 
that a standardized label is easier to understand and point out that consumers are boundedly rational, which means that they face both time and cognitive constraints, when interpreting environmental labels. Karl and Orwat (1999) argue that "a single sign avoids an 'information overload situation, which can be caused when limited information processing ability is confronted by large amounts of information ${ }^{13}$. Up to a specific level, consumers' ignorance is efficient, because consumers use a proxy which is more cost-effective than a direct measurement of environmental promises (Barzel, 1982). Frequently, the effectiveness of such cognitive supports depends more on the reputation and status of the third party, e.g. environmental associations, than the precise knowledge of the methods of its intervention. Moreover, the level of information provision is likely to differ according to the product considered. Higher information content may be more suited for decisions about more important purchases e.g. durable goods like cars, washing machines. Consumers may also place more weight on environmental characteristics when buying more frequently purchased products as their high frequency of purchase allows the consumer to perceive themselves as making a larger environmental impact $\left(\mathrm{O}^{\prime}\right.$ Brien and Teisl, 2004). Frequency of purchase also can lead to more exposure to the eco- label and its message; thus increasing the eco-labels impact (Thøgersen, 2000).

\subsection{Reducing free riding and assurance problems by emphasizing private benefits}

In the real world, people contribute to public goods at levels that exceed the predictions of the neoclassical theory. Several explanations have been provided, such as the "warm glow" concept (i.e. the increased utility from the act of giving, rather than receiving) (Andreoni, 1990) or the presence of social pressure or private inducements (e.g. the contributor derives more important joint private benefits than others from providing a collective good) or even the "Veblen effect" for which consumption may be conspicuous, thereby having a status value (Ackerman, 1997). The assurance problem can be mitigated by "assurance contracts", i.e. contractual agreements that contribute to a collective good project. These contracts guarantee each party, that his contribution will not be wasted, e.g. by money back guarantees, if the collective good is financially under-supported (Schmidtz, 1991).

In the case of ecolabeled products, public good problems can be alleviated by tying them to private benefits which are emphasized. The initial development of this argument i.e. the private provision of public goods by tying them to goods which have low exclusion cost, can be found in Demsetz (1970). Note that Loureiro et al. (2003) suggest a 
similar rationale for organic and eco-labeled products but do not take into account the assurance problem. The association between public environmental attributes and private ones such as taste or health can come from labeling, but may also already exist in consumer's mind, regardless of scientific evidence. It is intuitively convincing that low chemical input production (good for the environment) may induce low pesticide residues in food (good for the consumer's health). Tying public attributes to private ones may reduce free riding and assurance problems by creating excludability. The market switches to a quasi-conventional one with private goods where environmental attributes are provided as joint benefits. The purchase driver remains conventional private benefits and environmental attributes are bundled in the product. People purchase ecofriendly products because they enjoy primarily the private attributes resulting from an environmentally friendly production. For example, Moon et al. (2002) show that "respondents who are more concerned about food safety associated with vegetables are more likely to be willing to pay a premium for the environmental attributes of agricultural products." Moreover, such an analysis explains why products claiming the provision of a local public good are more likely to succeed than one claiming the preservation of a global public good ${ }^{14}$.

Let us consider that agro-food products include private attributes like health or taste and public environmental attributes which are interlinked for consumers. Consider a conventional product $C$ on figure 3 . Let us assume that product $C$ is now produced with an ecofriendly process. It objectively becomes an ecofriendly product E. Let us now consider consumers' perception of product E. Due to the cognitive problems raised, the consumer's beliefs and marketing efforts, the consumer may perceive product $\mathrm{E}$ as having more (or less) environmental attributes than it has in reality. Consumers may perceive product $\mathrm{E}$ as having more private attributes than it really has. Consumers may then perceive product $\mathrm{E}$ as being product $\mathrm{P}$. In sum, consumers will value environmental attributes and subsequent signaling as a proxy for other attributes that are private.

For example, many consumers expect that agrofood products from an ecofriendly process will have a better taste than conventional products (Deliza et al., 1999; Johansson et al., 1999). Such a perceived better taste allows consumers to (1) mitigate the free riding and the assurance situations by emphasizing private benefits (2) attenuate information asymmetry because consumers use the verifiable attribute as an indicator of the ecofriendly claim credibility, without strictly proving its truthfulness (3) reduce information overload by focusing consumers' attention on a conventional and well-known dimension of food quality. Indeed, taste is then used as a proxy for the existence of related environmental attributes. Consumers may be more familiar with 


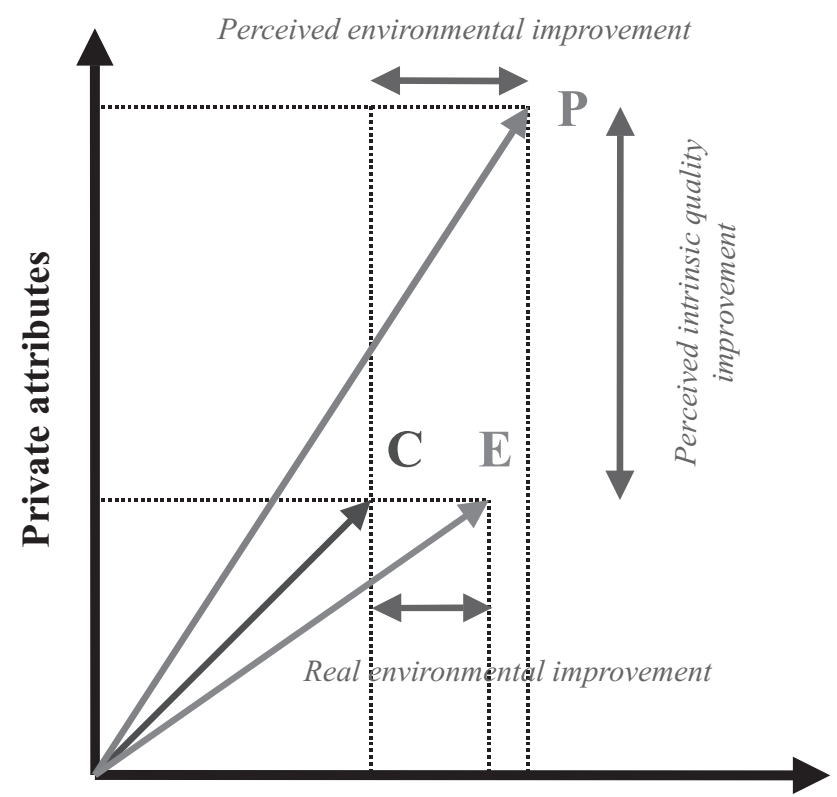

Public environmental attributes

Figure 3. Consumer perception of ecofriendly food products

information about taste that with information on the environmental characteristics. Consequently, they process it more easily.

Table 3 stresses that ecolabel designers want to switch from focusing mainly on public attributes, to emphasizing private attributes, and from credence attributes to verifiable indicators. Several examples of such a strategy are provided in the following section, where we show how several ecolabels attempt to mitigate these potential sources of market failures.

\section{HOW FRENCH AGROFOOD ECOLABELS MITIGATE MARKET FAILURES? AN EXPLORATORY ANALYSIS}

In France as in most European countries, agrofood products are not included in the governmental ecolabeling schemes. The arguments of this exclusion have been discussed elsewhere (Bougherara et al. 2003). Consequently, French agrofood ecolabels are mainly self-declared claims, which are made without third-party certification, by producers and retailers. To obtain the 'raw data', we have trained about 30 students preparing a master's degree who were in charge of investigating the most important and representative food stores in the metropolitan area 
TABLE 3

Guidelines to mitigate market failures in marketing ecofriendly products

\begin{tabular}{llll}
\hline $\begin{array}{l}\text { Types of } \\
\text { attributes }\end{array}$ & $\begin{array}{l}\text { Search } \\
\text { attributes }\end{array}$ & $\begin{array}{l}\text { Experience } \\
\text { attributes }\end{array}$ & $\begin{array}{l}\text { Credence } \\
\text { attributes }\end{array}$ \\
\hline $\begin{array}{l}\text { Public } \\
\text { attributes }\end{array}$ & $\begin{array}{l}\text { Packaging } \\
\text { material }\end{array}$ & $\begin{array}{l}\text { Waste volume }- \\
\text { Compressibility }\end{array}$ & $\begin{array}{l}\text { Environmentiai } \\
\text { process }\end{array}$ \\
$\begin{array}{l}\text { Private } \\
\text { attributes }\end{array}$ & $\begin{array}{l}\text { Aspect of an } \\
\text { apple }\end{array}$ & $\begin{array}{l}\text { Taste of an apple } \\
\text { Tafkaging }\end{array}$ & $\begin{array}{l}\text { Safety attributes } \\
\text { of an apple }\end{array}$ \\
\hline
\end{tabular}

of Dijon (France) in January 2002. They bought all agrofood products bearing an ecolabel. According to a specified framework, a qualitative analysis was conducted to identify the way ecolabel designers mitigate the three previously identified problems. Note that our sample is too small to draw any accurate quantitative analysis. So the percentages given are only indicative (Table 4).

The analysis shows that food ecolabels use especially the association of public and intangible environmental attributes with private and/or verifiable attributes such as health or taste. This may be specific to food products for which the link between the two kinds of attributes is often already in consumer's mind. A more in depth examination of ecolabels allows an interesting insight about the confusion, seemingly sustained by marketers' efforts, that exists between the impact of the production process on the environment and the impact of the environment on food products. For example, on a well-known bottle of mineral water, the producer claims that "the spring [...] benefits from a natural preserved environment"15. This water coming from a preserved environment says nothing about the environmental efforts performances of the producer. Rather it is referring to the absence of contamination of the bottled water by the production site. The Mac Cain ecolabel claims that the firm "selects safe fields [...] to plant its potatoes"16. The firm focuses on selecting a safe or non polluted place in order to reduce the risk of environmental contamination of potatoes. It does not promise to decrease the environmental impact of production practices. Besides, some French retailers argue that their fresh products are grown far from any source of pollution e.g. a freeway or a dump. They use this argument to substantiate environmental claims. According to the French Commission Nationale des Labels et des Certificats ${ }^{17}$, the focus of these claims is product safety, not an environmental improvement. Indeed, these practices protect agrofood products from contamination by a polluted 


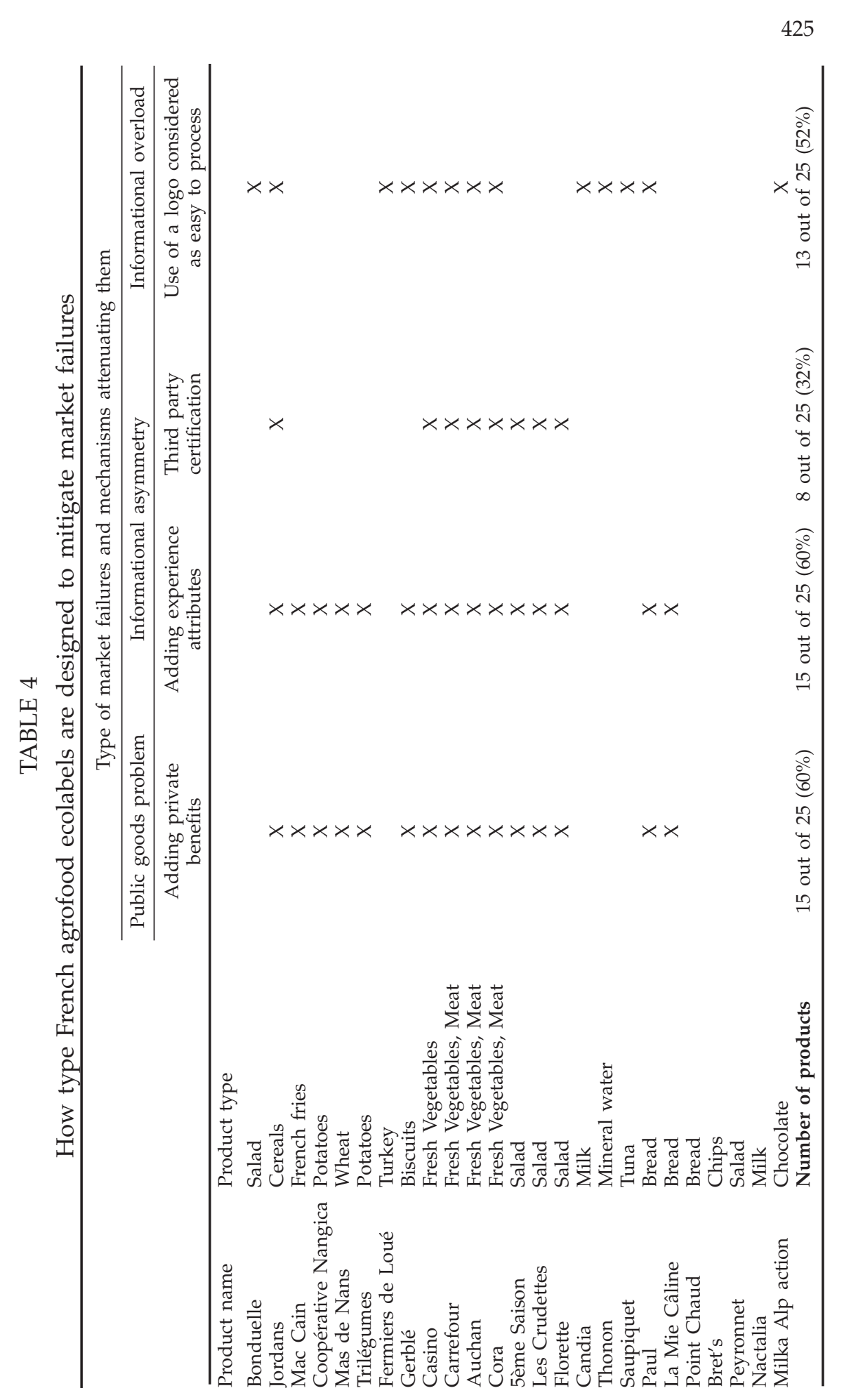


environment, but they do not produce environmental goods. It is wellknown that environmental claims are frequently spurious and generate consumers' confusion between a "preserved area" and an environmental friendly process of production, i.e. the protection of environment. Many claims are narrowly focused and respond more to safety concerns than to environmental ones (Leubuscher et al., 1998). Other mechanisms enabling consumers to trust ecolabels appear through the analyzed ecolabels. Given that numerous products are branded, reputation assets can be transferred on the environmental attributes making them more credible (Sporleder and Goldmsith, 2001). Moreover, some ecolabels refer to sponsoring by organizations such as the World Wide Fund For Nature (WWF) or the French National Forest Agency (ONF) that can generate environmental spillovers capable of reinforcing the credibility of the seller's claims. Such reputation interactions may also lead to perverse effects, such as projecting the green image on other products of the same firm that are not covered by the agreement between the environmental activists and firm (Grolleau, et al., 2004).

\section{SOME POLICY CONSIDERATIONS AND CONCLUDING REMARKS}

To mitigate simultaneously the previously identified sources of market failures - asymmetric information, limited cognitive abilities and public goods problems - ecolabel design matters. Ecolabel design determines its overall effectiveness by communicating trustworthiness, constituting a cognitive support and tying public attributes to private ones. Although ecolabeling can be an alternative to mitigate the previous market failures, a careful analysis is necessary to assess that this instrument is not more costly than the market failures it attempts to alleviate and other solutions. Indeed, in some cases we can just shift from a market failure to an ecolabel failure and dissipate money. Consumers' willingnesses to pay may be wasted in high transaction costs rather than used to improve environmental quality. In a coasean framework, the use of ecolabels as an alternative to another policy tool is efficient if the costs of designing, implementing and running ecolabeling schemes are lower (1) than those of the other solutions to mitigate market failures including the laissez faire and (2) than its expected benefits. Policy makers can play important roles by defining the 'rules of the game' which may shape the end result in terms of environmental effectiveness and economic efficiency. These rules include parameters such as participation rules for different interest groups, property rights to use environmental claims, anti-deception laws and level of enforcement. Moreover, consumers' inferences have important managerial implications for producers. They cannot rely on only third party disclosure to ensure the credibility of 
their claims but have to invest in the production of related attributes, even if the inferences based on them are subjective. There are clearly several issues left to investigate. The success of ecolabeling schemes requires the identification of the optimal level of information provision, which may differ significantly from symmetric or complete information. Lastly, assessing ecolabels overall effects is rather complex and would need further theoretical analysis and empirical studies. The multiple dimensions of ecolabeling has opened a large field of investigation certainly still to be deepened.

\section{NOTES}

1 We are indebted to Luc Thiébaut for stimulating conversations and constant encouragement. We greatly appreciate the comments of the referees. A preliminary version of this paper has been presented at the Conference on Ecolabels and the Greening of the Food Market, November, 7-9, 2002, Tufts University, Boston, MA. We thank the French Agency for Environment and Energy Management (ADEME), the Regional Council of Burgundy, the Scientific Committee of the ENESAD and the Inter-Institutional Program for Research in Environmental Economics (PIREE) for their financial support. The usual disclaimer applies.

2 Unlike the economic literature that uses the term "characteristics" for features of a product that are objectively measured and the term "attributes" for features that are perceived by consumers, we use the two terms interchangeably.

3 According to Beales et al. (1981), the demand for attribute information derives from the demand for attributes themselves. The willingness to pay for attribute information is bounded by the willingness to pay for the attributes themselves. This hypothesis enables us not to take into account situations where information disclosure generates a utility that is not linked to the consumption of the attributes themselves, such as environmental activists who are willing to acquire information at a high cost. Indeed, their willingness to pay for information is not derived from the demand for attributes.

4 Some credence attributes do not correspond to an informational asymmetry between seller and purchaser but to, incompleteness, uncertainty and controversies shared by all agents. Scientific knowledge is not established and nobody can probabilize the future, like about health effects of genetically modified organisms (GMO) or global climatic change.

5 For a similar argument, see Rogerson (1983).

6 Herbert Simon, in Scientific American, September, 1995, p. 201.

7 For example, Green Cross is a US environmental report card, which provides detailed and graphical information about performance and environmental impacts of the product, based on a cradle-to-grave study of the product, without value judgement. The report card resembles a nutritional label and aims at allowing the purchaser to compare the environmental burden of one product relative to another.

8 Federal Protection Agency, 2002, The Blue Angel Makes a Fresh Start - New Paths to Public Awareness, Umweltzeichen Newsletter, 5: 1-2.

9 In some cases, certain consumers may want to reduce the environmental impacts of their own consumption and the transaction can be considered as involving private goods. Others care about the whole environmental quality and face a true public good problem. We also admit some environmental characteristics provide private benefits e.g. less consumption of energy during the consumption phase, 
longer durability or less packaging. However, we consider that the environmental characteristics of ecofriendly products are mainly public goods.

10 To describe this internal conflict, Sagoff (1988) states "I love my car; I hate the bus. Yet I vote for candidates who promise to tax gasoline to pay for public transportation. I send my dues to the Sierra Club to protect areas in Alaska I shall never visit. [...] I have an "Ecology Now" sticker on a car that drips oil everywhere it's parked."

11 There is a lack of studies devoted to this first stage despite its significant implications. For example, the claim "GMO free" supposes a previous definition of GMO product itself, the choice of a detection threshold and the level of investigation of the food into agrofood chain, e.g. what is about cow's milk bred with GMO cereals? Because of the individual consumer inabilities to define his desired level of environmental quality, the environmental criteria are thus often settled by consulting all the parties e.g. industry, environmental and consumers associations, unions. Some parties may influence the environmental criteria to make them as close as possible to their preferences. Firms attempt to influence products' criteria in order to get the ecolabel without making any environmental efforts or to exclude competitors (Nadaï, 1998). West (1995) states that, "in practice, the needs of industry often take precedence over those of other interest groups in the decision-making process". In the case of the European Ecolabel for washing machines, he also relates that "all German manufacturers were able to meet the criteria from the beginning", or that "in the Netherlands, 60 percent of the tissue paper produced could meet standards without change to manufacturing practices". This situation leads West (1995) to the following statement: "voluntary eco-labeling scheme are rapidly degenerating into a means whereby industry can set the standard it likes".

12 More formally, a signal is effective if it leads to a separating equilibrium which requires the following sufficient conditions: (1) High ability agents can acquire the signal at a lower cost than low ability agents; (2) For high quality agents, the expected profit with a signal minus the cost of acquiring the signal is greater than the expected profit without the signal. (3) For low quality agents, the expected profit without signal is greater than the expected profit minus the cost of acquiring the signal (Macho Stadtler and Castrillo, 1997).

13 Some consumers might not feel sufficiently informed by a single sign, which prevent them from exercising their consumer sovereignty. More in depth research is necessary to compare welfare loss and gains resulting from information reduction.

14 Note that a local public good, e.g. a neighbouring countryside, can also have an advantage because it is more verifiable than a global public good, e.g. the state of the ozone layer.

15 Translated from French.

16 Translated from French.

17 French Agency of Agro-food Labels.

\section{REFERENCES}

Ackerman, F. (1997). Consumed in Theory: Alternative Perspectives on the Economics of Consumption. Journal of Economic Issues, 31: 651-664.

Akerlof, G. (1970). The Market for Lemons: Quality Uncertainty and Market Mechanism. Quarterly Journal of Economics, 84: 488-500.

Andreoni, J. (1990). Impure Altruism and Donations to Public Goods: A Theory of WarmGlow Giving? Economic Journal, 100: 464-477.

Bougherara, D., Grolleau, G. and Thiébaut, L. (2003). Mise en Perspective et Discussion de $l^{\prime}$ Exclusion des Produits Agro-alimentaires du Dispositif d'Écolabellisation. Economie Rurale, 275: 83-90. 
Anderson, M., Hollingsworth, C., Van Zee, V., Coli, W. and Rhodes, M. (1996). Consumer Response to Integrated Pest Management and Certification. Agriculture, Ecosystems and Environment, 60: 97-106.

Barzel, Y. (1982). Measurement Costs and the Organization of Markets. Journal of Law and Economics, 25(1): 27-48.

Blend, J.R. and Van Ravenswaay, E.O. (1999). Measuring Consumer Demand for Ecolabeled Apples. American Journal of Agricultural Economics, 81(5): 1078-1083.

Caswell, J.A. and Modjuszka, E.M. (1996). Using Informational Labelling to Influence the Market for Quality in Food Products. American Journal of Agricultural Economics, 78: $1248-1253$.

Commission for Environmental Cooperation (1999). Measuring Consumer Interest in Mexican Shade-grown Coffee: An Assessment of the Canadian. Mexican and US Market. Montreal, Quebec.

Darby, M.R. and Karni, E. (1973). Free Competition and the Optimal Amount of Fraud. Journal of Law and Economics, 16: 67-88.

Demsetz, H. (1970). The Private Production of Public Goods. Journal of Law and Economics, 13(2): 293-306.

Deliza, R., Rosenthal, A., Hedderley, D., MacFie, H.D. and Frewer, L.J. (1999). The Importance of Brand, Product Information and Manufacturing Process in the Development of Novel Environmentally Friendly Vegetable Oils. Journal of International Food and Agribusiness Marketing, 10(3): 67-77.

Govindasamy, R., Italia, J., Thatch, D. and Adelaja, A. (1998). Consumer Response to IPM-grown Produce. Journal of Extension, 36(4). Available at http://www.joe.org/joe/ 1998august/rb2.html.

Granatstein, D. (2000). Emerging Ecolabels for Food Products. Center for Sustaining Agriculture and Natural Resources Washington State University, Wenatchee, WA.

Hurley, S.P. and Kliebenstein, J.B. (1999). The Potential For Marketing Pork Products with Embedded Environmental Attributes: Results from an Experimental Study. American Agricultural Economics Association, Annual Meeting, August 8-11, Nashville, Tennesee.

Johansson, L., Haglund, Å., Berglund, L., Lea, P. and Risvik, J.E. (1999). Preference for Tomatoes, Affected by Sensory Attributes and Information about Growth Conditions. Food Quality and Preference, 10(4-5): 289-298.

Karl, H., Orwat, C. (1999) Economic Aspects of Environmental Labelling, in H. Folmer and T. Tietenberg (eds), Yearbook of Environmental and Resource Economics 1999/2000, Edward Elgar Cheltenham (UK), p. 107-170.

Leibenstein, H. (1987). Inside The Firm, Harvard University Press, Cambridge, MA.

Leubuscher, S., Hager, W., Wattiez, C., Mombrù, J. and Liaska, E. (1998). Study on Verification and Control of Environmental Product Claims. Final Report by Prospect C\&S for DG Health and Consumer Protection.

Loureiro, M.L., McCluskey, J.J. and Mittelhammer, R.C. (2002). Will Consumers Pay a Premium for Eco-labeled Apples? Journal of Consumer Affairs, 36(2): 203-219.

Loureiro, M.L., McCluskey, J.J. and Mittelhammer, R.C. (2003). Are Stated Preferences Good Predictors of Market Behavior? Land Economics, 79(1): 44-55.

Margolis, H. (1982). Selfishness, altruism and rationality. Cambridge, Cambridge University Press, MA.

Macho-Stadler, I. and Perez Castrillo, D.J. (1997). Introduction to the Economics of Information: Incentives and Contracts. Oxford: Oxford University Press.

McCLuskey, J. (2000). A Game Theoretic Approach to Organic Foods: An Analysis of Asymmetric Information and Policy, Agricultural and Resource Economics, 29: 1-9.

Moon, W., Florkowski, W.J., Brückner, B. and Schonhof, I. (2002). Willingness to Pay for Environmental Practices: Implications for Eco-Labeling, Land Economics, 78(1): 88-102.

Nadaï, A. (1998). Concurrence dans la Qualification Environnementale des Produits. Revue d'Economie Industrielle, 83: 197-212. 
Nelson, P. (1970). Information and Consumer Behaviour. Journal of Political Economy, 78: 311-329.

O'Brien, K.A. and Teisl, M.F. (2004). Eco-information and its effect on consumer values for environmentally certified forest products, Journal of Forest Economics, 10(2): 75-96.

O'Reilly, C.A. (1980). Individuals and Information Overload in Organizations: Is More Necessarily Better?, Academy of Management Journal, 23(4): 685-696.

Rahmann, G., Ashworth, S.W., Boutonnet, J.P., Brunori, G. and Papadopoulos, I. (2001). Opportunities and Barriers for Niche Marketing of Lamb in European LFAs based on consumer attitudes to product quality. Agrarwirtschaft - German Journal of Agricultural Economics, 50: 293-301.

Sagoff, M. (1988). The Economy of the Earth, Cambridge University Press, Cambridge.

Schmidtz, D. (1991). The Limits of Government, An Essay on the Public Goods Argument, Westview Press.

Sporleder, T.L. and Goldsmith, P.D. (2001). Alternative Firm Strategies for Signaling Quality in the Food System, Canadian Journal of Agricultural Economics, 49(4): 591-604.

Teisl, M.F. and Roe, B. (1998). The Economics of Labeling: An Overview of Issues for Health and Environmental Disclosure, Agriculture and Resource Economics Review, 27: 140-150.

Thøgersen, J. (2002). Promoting "Green" Consumer Behavior with Eco-Labels, in New Tools for Environmental protection, edited by T. Dietzand and P. Stern, Washington, DC: National Academy Press Chapter 5: pp. 83-104.

West, K. (1995). Ecolabels: The Industrialization of Environmental Standards. The Ecologist, 25(1): 16-21.

Wiener, J.L. and Doescher, T.A. (1991). A Framework for Promoting Cooperation, Journal of Marketing, 55(2): 38-47.

Wynne, R.D. (1994). The Emperor's New Ecologos? A Critical Review of the Scientific Certification Systems Environmental Report Cards and the Green Seal Certification Mark Programs. Virginia Environmental Law Journal, 14: 51-149. 